\title{
Begat: The King James Bible and the English Language, by David Crystal
}

Oxford: Oxford University Press, 2010 | vii + 327 pages | ISBN: 978-0-I9-958585-4 (hardback) £I4.99 | ISBN: 978-0-I99695 I $8-8$ (softback) $£ 8.99$

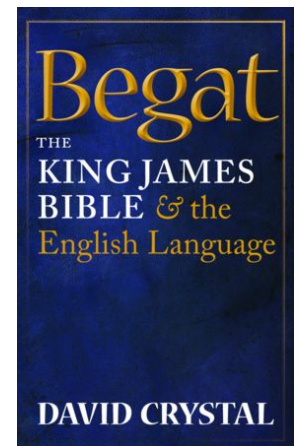

A common—and valid—criticism of the reception history of the Bible is that, too often, papers at conferences are little more than a cataloguing of where this or that biblical verse or topic occurs with little concern for cultural, ideological, historical, etc. concerns. If cataloguing did have a place it might be argued that it would be as a resource for future work on a given area of biblical reception. This is precisely where David Crystal's exceptionally helpful Begat comes into its own. Rather than focusing on the origins and production of the King James Bible (KJB), Crystal takes us through a wide range of famous phrases from the KJB (or King James-sounding phrases) and their receptions in low and high culture. We therefore get chapters on "Let there be light," "My brother's keeper," "Begat," "Bread alone," "Heal thyself," and so on. Crystal does attempt to count the number of King James Bible expressions which have had "a permanent influence on the development of the English language” (2). This is not an easy task given the problems involved in establishing whether expressions come from the KJB or a relevant other Bible. Crystal also sets this up as a plot surprise in his first of two prologues to be revealed in the Epilogue; so in the spirit of things, there will be no spoilers here. 
The faux exasperation (read: "aren't I clever!") expressed by certain reviewers of Begat at recollecting "more important" (read: higher culture) references than Crystal completely misses the point. For example, Christopher Hirst, writing in The Independent (London), argued,

Some of Crystal's omissions are baffling. We learn that "my brother's keeper" (Genesis 4:9) was a pilot episode of Miami Vice but not that it was used for the autobiography of Stanislaus Joyce (brother of James). Crystal's exploration of "kick against the pricks" (Acts 9:5) cites a Guardian football report but not the Samuel Beckett collection More Pricks than Kicks. ${ }^{4}$

But choosing examples Hirst would prefer over ones actually given in Begat, whether because they sound more intellectual or because they are associated with figures deemed culturally more important, would in some ways undermine Crystal's very argument on the perpetuation and survival of the various idioms from the KJB throughout the English-speaking world (certainly in the West). Crystal argues that idioms are adapted, often with comical intent, with all sorts of unexpected language play (e.g., "Am I my brothel's keeper?" 27), which is central to his analysis of the extent to which these idioms have "permeated genres of modern spoken or written English" (26I), such as e.g., marketing, journalism, sport, theatre, punk music, computing. Likewise, one of the key reasons (e.g., 26I) for survival of idioms (and not necessarily in the same form found in the KJB) is a range of phonetic properties, such as iambic rhythms (e.g., "how the mighty have fallen!" 75 ) and rhyme, or indeed words which lend themselves to rhyme and thus adaptation (e.g., "grave" as in "From the cradle to the grave," 85 ). It is not, therefore, "baffling" why Crystal chooses the kinds of examples he does: he has not written a book about how English is written and spoken in intellectual or polite circles alone (still, sadly, too often the assumption of many academics and intellectuals today, in my experience).

But while the KJB and its reception (linguistically accurate or otherwise) have shaped a number of well known English idioms, there are a number of King James-sounding idioms which have come from other influential Bibles since eclipsed (e.g., Wycliffe, Tyndale) but effectively colonised by the KJB

${ }^{4}$ Christopher Hirst, "Begat, by David Crystal", The Independent, 3oth September 20 I I, http://www.independent.co.uk/arts-entertainment/books/reviews/begat-by-david-crystal-2 362935 .html. 
in its reception. Crystal simultaneously points out that there is little evidence for lexical innovation and assumptions about grammatical innovation need proper studies. In this sense, the KJB is little more than a book of witty or useful idioms and, in this sense, may not be quite the influential book as is commonly suggested. Crystal's book is, therefore, something more than simply a resource for the reception of idioms from the KJB: underpinning the book are ideas about the "hows" and "whys" of the reception and, as this seems so culturally widespread in the English language, there is, again, no reason to resort to making sure everyone knows the reviewer knows about Beckett and Joyce's brother.

A dominant and important result from the analysis of this collection of idioms is that "the items discussed in this book are not quotations: they are everyday expressions used by speakers and writers of modern English, most of whom will have no religious motivation for their use" (257). This decaffeinating of the Bible, or removing anything deemed too "religious," is one of the ways in which the Bible continues to survive in Western cultural contexts striving to come to terms with secularism, nationalism, and global capitalism. ${ }^{5}$ The KJB is no longer the powerful book of the Crown or the British Empire but increasingly tied in with what Yvonne Sherwood called the "Liberal Bible," i.e., a dominant Western interpretation of the Bible as supporting democracy, freedom, rights, etc., but now increasingly used in a vague manner so as to be a dog whistle to the believer without putting off those more nervous about things "religious." This is the Bible, then, deprived of its problematic pre-modern otherness. No Gentile dogs, no burning in the time to come, no strange purity laws, no genocide and so on. This Bible, like the construction of "religion" more generally, has to be made palatable for liberal democratic ideals and thus anything too problematically "religious" must go. And it is the KJB which is most embedded in many world cultures using the English language, and in English-speaking Western cultures where the Bible has a nervy relationship with the political elite.

Some fairly typical examples from the British press which invariably use the KJB might include "love thy neighbour" or "render unto Caesar." For instance, Dominic Lawson claimed (somehow) that the present Pope is "apolitical" and "has no interest in inserting the Catholic Church into the polit-

${ }^{5}$ I am alluding to Slavoj Žižek, e.g., The Puppet and the Dwarf: The Perverse Core of Christianity (Cambridge: MIT Press, 2003), 96: "On today's market, we find a series of products deprived of their malignant property: coffee without caffeine, cream without fat, beer without alcohol." 
ical process." This is because the Pope inherited his world view from Jesus, who declared, as Lawson summarises, "that the temporal and spiritual worlds should be entirely separate." And what precisely did Jesus declare? Only one of the more favoured quotations from the Bible, "Render unto Caesar the things that are Caesar's and unto God the things that are God's"! Also in the context of Benedict XVI's visit to the UK in 20 Io, the Daily Mail quotes the Catholic MP Mark Pritchard as saying "The Catholic Church is an imperfect institution but it is amazing the $\mathrm{BBC}$ has found nothing positive to say about a church whose key message is to love thy neighbour including feeding the poor and helping the homeless" (cf. Begat, I9I-92). ${ }^{7}$ Of course, transubstantiation, sin, salvation, sacraments, anti-contraception, and so on might alternatively be thought of as central to perceptions of Catholic history but that is not the point: once in the contemporary political arena and needed to be seen as acceptable, 2000 years of history is easily boiled down to "love thy neighbour." There are plenty more examples to be discussed another time but, for now, we might add that, in its own imitable way, this is the sort of thing that is going on in Crystal's fantastic collection of ironic, punning, clever, but ultimately harmless examples (and it is no surprise the KJB has found a friend in marketing and we might note the use of the language of born again among politicians to refer to contemporary political affiliations [2I2]).

In other words, a non-threatening Bible survives in dominant political discourses because it is the best way it can, without being thrown out. In its Golden Age, the KJB was the Bible of Empire; it now serves a new master which does not go to Church quite as much as its predecessors: liberal parliamentary democracy of "late" capitalism. And if it knows what's good for it, the KJB had presumably better keep on behaving as the cute little wisecracking kid with a heart it has become.

James G. Crossley

University of Sheffeeld

\footnotetext{
${ }^{6}$ Dominic Lawson, "Pope Benedict ... an apology", The Independent, 2 Ist September 20 Io, http://www.independent.co.uk/opinion/commentators/dominic-lawson/dominic-la wson-pope-benedict-an-apology-2084788.html.

${ }^{7}$ Steve Doughty, "Pope faces atheist hate campaign in UK after top German aide says: "When you land at Heathrow you think you're in a Third World country", Daily Mail (I6th September 20I0), http : / / www . dailymail . co . uk / news / article - I 3 I 228 5/POPES-UK-VISIT-Benedict-XVI-faces-atheist-hate-campaign.html.
} 